\title{
A Framework for Considering Climate Change Impacts in Project Selection for Deepwater Horizon Restoration Efforts
}

\author{
Bethany Carl Kraft ${ }^{1,2}$ (D) $\cdot$ Raelene Crandall ${ }^{2}$
}

Received: 28 May 2019 / Accepted: 12 September 2019 / Published online: 12 November 2019

(C) The Author(s) 2019

\begin{abstract}
The 2010 Deepwater Horizon (DWH) oil spill resulted in extensive damage to the northern Gulf of Mexico ecosystem. Resulting fines and penalties have triggered one of the largest ecological restoration efforts in U.S. history. Nearly \$20 Billion in funding from oil spill-related claims and settlements will be available in the coming years for environmental restoration and economic recovery. At the same time, climate change is also impacting ecosystem form and function in the Gulf region, which could undermine the long-term sustainability of projects by limiting their useful life or impeding anticipated benefits over time (e.g., ecosystem services, flood protection). These challenges can be considered and addressed in project planning, selection and adaptive management phases of restoration. If decision-makers do not consider the longevity of projects in the face of climate-related stressors, in 30 to 50 years there could be very little to show for a $\$ 20$ Billion investment, with the Gulf ecosystem still in need of extensive restoration but without the monetary resources to accomplish restoration goals and mitigate climaterelated impacts. This paper provides a framework for decision makers to consider how to incorporate climate change considerations for wetland restoration activities related to the DWH spill.
\end{abstract}

Keywords Deepwater horizon $\cdot$ Restoration $\cdot$ Climate change $\cdot$ Decision-making $\cdot$ Wetlands restoration

\section{Introduction}

The Gulf of Mexico is the ninth largest body of water in the world and supports a diverse array of wildlife, habitats and ecosystem functions (NOAA 2011). The natural resources of the Gulf region also drive the coastal economy, with the five states bordering the Gulf of Mexico contributing over $\$ 3$ trillion to the national Gross Domestic Product in 2016 (BEA 2017). The 2010 Deepwater Horizon (DWH) oil spill caused extensive damage to the marine and coastal/estuarine ecosystems and economy of the Gulf region, resulting in "an injury to the entire ecosystem of the northern Gulf of Mexico" according to the Deepwater Horizon Natural Resource Damage Assessment (NRDA) Trustees (DWH Oil Spill Trustees 2016). The DWH disaster further exacerbated the declining

Bethany Carl Kraft

Bethany.kraft@volkert.com

1 Volkert, Inc., 1110 Montlimar Drive, Ste 1050, Mobile, AL 36670, USA

2 University of Florida, Gainesville, FL, USA health and function of Gulf ecosystems and economies which have suffered from decades of significant human and natural stressors, including: (1) chronic loss of critical wetland habitats; (2) erosion of barrier islands; (3) imperiled fisheries; (4) water quality degradation, including the annual appearance of a hypoxic dead zone that was the size of New Jersey in 2017; (5) impacts from invasive species; (6) substantial coastal land loss due to natural forces; (7) alteration of hydrology; and (8) impacts from other human activities such as oil and gas exploration (Gulf Coast Ecosystem Restoration Task Force 2011). In addition, the Gulf region has endured repeated natural catastrophes, including major hurricanes such as Katrina, Ike, Harvey and Irma (Bregy et al. 2018). Climate change, and sea level rise (SLR) in particular, compound this vulnerability, putting natural resources, human communities and billions of dollars in infrastructure at risk in the coming decades.

The DWH oil spill resulted in over \$20 Billion in fines and penalties that will be expended from the present until at least 2031 for recovery and restoration of the Gulf region's ecosystem and economy. Depending on the funding allocation, these fines and penalties can be used to implement projects that address impacts directly related to the spill as well as projects that address historic degradation or mitigate future threats. 
This presents an unprecedented opportunity to restore ecosystem condition and function if the full suite of environmental stressors, including climate impacts, are fully considered in evaluating and selecting projects. Underscoring the importance of maximizing project investments is the fact that the \$20 Billion available will will not fully address all of the restoration needs in the region. For example, the cost to implement the State of Louisiana's five-year Coastal Master Plan for restoration is estimated by the Coastal Restoration and Protection Authority to cost $\$ 50$ Billion to implement over fifty years (CPRA 2017), an estimate that does not take into account inflation over that time, raising the cost of implementation to over $\$ 100$ Billion in today's dollars (Davis and Boyer 2017). Because of the scale of restoration needs and the uncertainty of when -or if- additional funding will become available, well-defined citeria should be used to select projects that will provide long-term as well as short-term benefits, which will assist in reducing future costs of restoration. Projects that provide ecosystem benefits in addition to providing protection or adaptation benefits to human communities and infrastructure (e.g., wetlands restoration projects that mitigate storm surge for coastal communities) are potentially cost-effective ways to reduce current and future risks and result in benefits that are compounded over time as risks increase and mitigation becomes more expensive (Reguero et al. 2018). Additionally, the real dollar value of restoration funding available today will decrease over time due to inflation, making projects implemented today functionally less expensive than the same project implemented in the future. These financial considerations underscore the value of utilizing current funding in ways that will maximize returns on investment over time.

Climate change is expected to significantly impact Gulf region ecosystems in the coming decades, with the areas most vulnerable to climate change overlapping geographically with the program areas for DWH restoration efforts. To assist decision-makers in selecting projects that are more likely to persist even as climate change impacts manifest and sea level rise continues, we identify a qualitative framework for considering future anticipated conditions in project selection activities in order to achieve short-term project objectives while potentially maximizing long-term project benefits and monetary investments.

\section{DWH Funding Processes and Restoration Targets - An Unprecedented Opportunity}

In 2016, the U.S. Government entered into a consent decree with BP, plc (formerly The British Petroleum Company plc but known as BP) for the resolution of civil claims for the Deepwater Horizon oil spill. Settlements with other responsible parties, including Transocean and Anadarko preceded the
2016 BP settlement. The majority of the BP penalties and fines will be paid out over a fifteen- year period, which began in April 2016 (Department of Justice 2016). Although this payout schedule presents challenges for implementing largescale projects that exceed the amount available in any given year, it does allow time for adaptive management and iterative planning activities to take place. Three primary processes govern the selection of projects and distribution of funds related to the oil spill: (1) the Natural Resource Damage Assessment Process (NRDA), which is implemented under the Oil Pollution Act of 1990; (2) the Gulf Environmental Benefit Fund, a 5-year, \$2.54 Billion program created to address oil spill impacts and mitigate future harm, overseen by the notfor-profit National Fish and Wildlife Foundation; and (3) the RESTORE Trust fund, created by the 2012 RESTORE Act, which directed $80 \%$ of all civil penalties levied against responsible parties to the Gulf region, overseen by the Department of Treasury and the Gulf Coast Ecosystem Restoration Council for the purposes of ecosystem restoration, economic recovery and tourism promotion (Kim 2015; ELI 2014). These restoration entities operate on different funding allocation cycles and have different, but in many cases overlapping, decisionmakers, and generally share common restoration targets and goals.

The flow of resources through various federal and state agencies is extremely complex, with some being relatively prescriptive (e.g., the NRDA funds which are parsed by state, region and restoration type), while other funds have very few limitations. The RESTORE Act's Council-Selected Restoration Component has a particularly challenging decision-making process, balancing shifting political agendas while still being informed by "best available science," including impacts of rising sea levels along the Gulf Coast. The responsibility of selecting ecosystem restoration projects totalling \$1.6 Billion (plus 50\% of the interest from those funds) through 2031 was given to an 11 member Council, composed of the Governors of the five Gulf Coast States, the Secretaries from the U.S. Departments of the Interior, Army, Commerce, Agriculture, and Homeland Security, and the Administrator of the U.S. Environmental Protection Agency. The Gulf Coast Ecosystem Restoration Council's Comprehensive Plan acknowledges climate change as a stressor, but the document does not identify how or if this impacts decision-making. Decision-making for restoration projects funded thus far under Bucket 2 (approximately $\$ 180$ Million) appear to be somewhat science-based (although it is not clear if the science drives the project selection or project selection drives the accompanying science narrative) but also clearly favors selection of projects identified in existing plans that may or may not consider climate change. It is also clear that some level of funding decisions have been based on concepts of funding parity and sovereignty for the five Gulf states (see Gulf Coast Ecosystem Restoration Council Comprehensive Plans 
2013, 2016) as funding distributions across processes have been generally equitable for Texas, Mississippi, Alabama, Florida, and most of the federal members with ecosystem restoration as part of their agency mission, with projects within the State of Louisiana the only exception, receiving approximately $33 \%$ (as well as $50 \%$ of both NRDA and NFWF funds), accounting for the fact that the majority of landbased impacts from the spill were documented in Louisiana.

The DWH NRDA Programmatic Damage Assessment and Restoration Plan/Programmatic Environmental Impact Statment (PDARP/PEIS) lays out a number of restoration targets and approaches for natural resources impacted by the spill. A review of available documents from NFWF and the RESTORE Council and past funding decisions reveals the close alignment of restoration goals amongst the three restoration entities (Baldera et al. 2018). Thus, we base the recommendations listed in this paper on the restoration resource types identified in the PDARP/PEIS, with an emphasis on the wetlands, coastal and nearshore habitats restoration type, which will receive over \$4 Billion in funding from the NRDA process alone (DWH Trustees 2016) and is a resource type that is particularly vulnerable to impacts from climate change (Table 1).

Generally, DWH planning documents acknowledge SLR as a stressor but do not provide information about how or if knowledge of SLR projections influences project selection. This is a weakness in existing DWH efforts as projects that fail to consider climate change in project selection processes and that lack robust adaptive management process (including concomitant monitoring strategies and funding) will be less effective in restoring ecological conditions and function,

Table 1 Deepwater Horizon Funding Processes

\begin{tabular}{|c|c|c|}
\hline Process & Purpose of Funding & $\begin{array}{l}\text { Total } \\
\text { Allocation } \\
\text { over Payout } \\
\text { Period }\end{array}$ \\
\hline $\begin{array}{c}\text { Natural Resource Damage } \\
\text { Assessment (NRDA) }\end{array}$ & $\begin{array}{l}\text { Restore natural resources } \\
\text { and human use and } \\
\text { enjoyment of natural } \\
\text { resources to where they } \\
\text { would have been if the } \\
\text { oil spill had notoccurred. }\end{array}$ & $\$ 8.1$ Billion \\
\hline $\begin{array}{l}\text { Restoration Trust Fund } \\
\text { (RESTORE Act) }\end{array}$ & $\begin{array}{l}\text { Money divided into } \\
\text { different allocations, but } \\
\text { generally can be used for } \\
\text { restoration and } \\
\text { protection of the } \\
\text { ecosystems and } \\
\text { economies of the five } \\
\text { Gulf Coast States. }\end{array}$ & $\$ 5.33$ Billion \\
\hline $\begin{array}{l}\text { National Fish and Wildlife } \\
\text { Foundation Gulf } \\
\text { Environmental Benefit } \\
\text { Fund (NFWF GEBF) }\end{array}$ & $\begin{array}{l}\text { Projects that benefit the } \\
\text { natural resources of the } \\
\text { Gulf Coast that were } \\
\text { impacted by the Spill }\end{array}$ & $\begin{array}{l}\$ 2.544 \\
\quad \text { Billion }\end{array}$ \\
\hline
\end{tabular}

threatening the success of the restoration effort. Several hundred million dollars of projects have been approved as of January 2019-these and future project decisions are being made in a complex political environment with dynamic tension between political drivers and priorities and ecosystem stressors. Compounding this already complex restoration effort are attitudes about climate change and its anticipated effects. For example, a study of coastal stakeholders on the Gulf Coast found that government employees were likely to be more skeptical of accepting climate change (Stoutenborough and Vedlitz 2015) than other coastal stakeholders, though climate change is a polarizing issue for the general public as well. This increases the difficulty for political decisionmakers to consider sea level rise as an explicit threat to project success.

\section{Climate Change in the Gulf of Mexico}

Sea level in the Gulf region has risen and then fallen periodically throughout the Holocene. The northwestern Gulf region experienced two periods of flooding events attributed to rapid sea level rise in the early Holocoene, and current rates of sea level rise and erosion in the region are approaching those early Holocene rates (Anderson et al. 2014). Global mean sea levels are projected to rise between $0.2 \mathrm{~m}$ and $2.0 \mathrm{~m}$ by 2100 , with portions of the western Gulf in Louisiana and Texas likely to have Relative Sea Level Rise (RSLR) of $0.3 \mathrm{~m}$ to $0.5 \mathrm{~m}$ more than Global Mean SLR by 2100, making the region particularly vulnerable to the impacts of coastal storms and rising seas (Powell et al. 2017). The complexity of coastal systems and the variables that influence an environment's response to climate change prevent precise forecasts for coastal response to SLR but the literature does agree on the types of coastal impacts expected along the Gulf Coast, including increased nuisance flooding, storm surge, inundation of wetlands and estuaries, saltwater intrusion into groundwater resources, erosion and damaged infrastructure (Pendleton et al. 2010). Marshes and wetlands that provide nursery habitat for commercial and recreationally important finfish and shellfish species as well as protection from storm surge and flooding for coastal communities are threatened by increased shoreline erosion and inundation (Anderson et al. 2014). Marshes that receive no sediment inputs and/or that are unable to migrate upland due to the presence of built impediments may not be able to respond to sea level rise and will become inundated over time (Passeri et al. 2015). Higher sea levels are expected to worsen already challenging issues that affect the success and longevity of restoration projects, including storm surge, wave impacts and higher tides (Theuerkauf et al. 2014). In addition to the effects of SLR, hurricanes have the potential to destroy progress made in restoration efforts, and studies suggest that future cyclonic activity will be less frequent but 
more intense and, typically, intense storms cause the most damage to natural and built environments (Morris et al. 2018).

Many of these effects are already being observed in the Gulf region, but uncertainty about the extent and timing of additional impacts in the near future make incorporating climate change effects in project planning and selection difficult. Most project decision-makers for the DWH restoration processes are political appointees, making it difficult to consider efforts beyond one election cycle, much less to account for possible conditions two and three decades into the future. Even in the short-term, making decisions regarding complex systems with extensive uncertainty is challenging, underscoring the importance of implementing projects in the context of an adaptive management framework where learning and innovation can take place.

The impacts of a rapidly changing environment will affect the viability and longevity of restoration projects, and as a key stressor, SLR could be considered in project selection to identify those projects that can either mitigate or withstand the impacts of SLR. If anticipated future conditions are considered during project selection and planning phases, restoration projects that are implemented stand a better chance of performing as designed for a longer period of time. They also will contribute to the overall health and resilience of the Gulf region, better equipping natural and human communities to withstand the impacts of a changing climate.

\section{Decision-Making under Uncertainty}

The complexity associated with predicting precisely when, where, how and to what extent climate change will manifest underscores the difficulty of making decisions based on incomplete and/or complex scientific information. Regardless, there is a general scientific consensus on how climate change will impact various regions, including the Gulf coast states (Estenoz and Bush 2015). Difficulties in predicting the extent and timing of effects nothwithstanding, climate change will impact the Gulf region (Estenoz and Bush 2015), which could affect the success of restoration efforts underwritten by DWH funding. Further complicating the decision process is the determination of the spatial scale to which decisions apply (town, county/parish, watershed, state, region) as well as the temporal projections $(10,20,30,50$ or 100 years). When incorporating future effects of climate change into presentday project selection, two primary questions should be addressed: Can the scientific evidence behind climate change effects be incorporated into the decision-making process, and if so, can the evidence be presented in a way that makes it easy for decision-makers to apply? Leaders frequently make decisions based on incomplete information, making do with the information they have at the time a decision must be made. In that regard, considering the impacts of climate change in projects is no different than the myriad other decisions made with high degrees of uncertainty.

There are a number of different approaches to consider when addressing the uncertainty of decisions under various climate change scenarios, including the use of scenario planning, decision theory, resiliency theory, portfolio theory and thresholds approaches (Crowe and Parker 2008; Polasky et al. 2011; Estenoz and Bush 2015; Mahmoud et al. 2009). The use of quantitative decision-making methods would be ideal, but most restoration decisions, in addition to being science-based to varying degrees, are made from an assessment of a number of qualitative factors including: promoting an even geographic distribution of projects, political pressures and the perceived need for the project (One exception is the State of Louisiana, whose Master Plan is based on extensive modeling efforts that take into account RSLR projections (CPRA 2017).

As a result, there exists a dynamic tension between decision-makers and those who provide information (in this case scientists from restoration ecology and climate fields of study) that can lead to a functional disconnect of information flow between them. Scientific information is often highly complex, as one would expect when making ecosystemlevel decisions; there is generally no completely right or completely wrong answer, and the decision-maker must balance scientific information provided with the social, economic and political information that is also provided to them. This is captured nicely in Dalyander et al. (2016): "Coastal ecosystem management typically relies on subjective interpretation of scientific understanding, with limited methods for explicitly incorporating process knowledge into decisions that must meet multiple, potentially competing stakeholder objectives. Conversely, the scientific community lacks methods for identifying which advancements in system understanding would have the highest value to decision makers." This disconnect between scientists and decision makers increases the likelihood of project failure by inhibiting communication that allows for the exchange of information and the acknowledgement that not all uncertainties can be resolved.

\section{Framework for Incorporating Climate Change into Project Selection}

The first funds for DWH-related restoration were made available in April 2011 (Ramseur and Hagerty 2014). In the ensuing years, both the Gulf Coast Ecosystem Restoration Council and the DWH NRDA Trustees have expended several hundred million dollars and developed a number of planning documents that acknowledge SLR and stressors, but there are no existing guidelines for selecting projects based on need, merit or potential for success, nor are there guidelines that provide for considering whether the extent or severity of identified stressors will prevent a project from achieving its restoration 
objectives. NRDA regulations limit the range of projects that can be funded to those that have a nexus to injury caused by the DWH oil spill and response effort; even so, for all funding programs, including those that could be funded under NRDA, there appears to be a gap in consideration of whether some projects may be more likely to succeed than others when taking into account projections for SLR. For example, Alabama and Mississippi have spent several million dollars of DWH funds to purchase marsh habitat in the Grand Bay Complex, situated on the Mississippi Sound. The Complex is relatively intact, with significant acreage already under public ownership, but it is sediment starved and experiencing rapid erosion, with SLR projections of $0.49 \mathrm{~m}$ to $1.86 \mathrm{~m}$ by 2100 and with limited ability for the marsh to migrate upland over time due to the presence of a railroad and highway (Strauss et al. 2015; Passeri et al. 2015). Unless actions are taken to maintain the marsh's elevation as SLR continues (e.g., via beneficial use of sediment), then the marsh will continue to erode in the coming decades and the ecosystem services and habitat the acquisition projects seek to conserve could literally be washed away (Peterson et al. 2007).

This underscores the importance of realistically evaluating what restoration objectives a project can reasonably achieve. Identifying restoration targets based on historic or even current conditions may not be the best way to ensure long-term viability of projects in a rapidly changing environment (Harris et al. 2006). In some cases, decision makers may understandably prioritize immediate but short-term benefits over longterm project viability to demonstrate to their constituents and political support structure that they are making visible and (relatively) immediate impacts. However, consideration of how to maximize restoration investments over time could position leaders to mitigate ecosystem and human risk at a relatively low cost compared to the expense associated with forced adaptation in the future (Reguero et al. 2018). Additionally, the DWH restoration effort is unfolding at a time when climate change is rendering historical conditions untrustworthy as a basis for project decision-making (Harris et al. 2006). To maximize the chances of achieving measurable benefits at the end of the $\$ 20$ Billion DWH restoration program, decision-making should take into account climate change and consider available information regarding expected impacts. The principles outlined below were developed with the expectation that complex decision-making metrics will likely not be utilized by funding decision makers and that any principles should account for near-term (three to five decades) SLR projections rather than projects for the year 2100. To that end, we based these principles on SLR projections of $0.41 \mathrm{~m}$ to $0.82 \mathrm{~m}$ for the year 2050 , which were derived from stepping down levels of $1.0 \mathrm{~m}$ and $2.0 \mathrm{~m}$ for the year 2100 as identified in the Global Sea Level Rise Scenarios for the United State National Climate Assessment (Watson et al. 2015).
Based on relevant literature and observation of DWH funding processes, the following framework was developed to provide guidelines for decision makers. By design, they are general in nature with the intent that a basic construct for consideration of future conditions will be easier to incorporate into an already complex decision-making environment.

1. Consider future conditions in project selection. In future iterations of DWH planning documents, project selection should explicitly consider the development of restoration objectives based on desired future conditions, and rely less on restoration of resources to some historic trajectory that may not be possible to achieve given changing conditions (Choi et al. 2008). Decisions should consider project self-sustainment and functionality over a defined period of time.

2. Invest in filling critical data gaps. As climate change increases the vulnerability of Gulf habitats and species, providing funding to fill data gaps related to critical species and ecosystem thresholds will help decision makers better understand which species and habitats are approaching their thresholds and require immediate intervention, and which are still in relatively stable states (Powell et al. 2017).

3. Adopt long-term thinking as part of the decisionmaking process. Environments (in particular, wetlands and barrier islands) likely to be inundated or otherwise affected under the 2060 SLR scenario of $0.41 \mathrm{~m}$ should not be prioritized for funding unless specific mitigation or adaptation activities are also undertaken to increase a project's resilience to SLR, or unless a project's restoration benefits are likely to persist despite current projections. As an example, marshes in areas experiencing high rates of RSLR with no source of sediment should not be prioritized for conservation unless restoration activities will also be conducted to maintain elevations necessary to maintain ecosystem form and function even as RSLR increases.

4. Prioritize projects and suites of projects that enhance landscape connectivity. Reducing habitat fragmentation is a key element of species' ability to migrate as climate changes (Enwright et al. 2016).

5. Consider potential changes in a species' range based on climate change. If restoration targets certain species or habitats, consider projects that provide pathways for migration or refugia if the restoration targets are likely to be impacted by climate change.

6. Prioritize projects in locations where management actions (economic, ecological and/or social) to reduce stressors are also underway. Incentivizing better resource management by prioritizing DWH funding in communities already working to address environmental 
stressors through local ordinances or management approaches could increase the likelihood of success for projects that are affected by human-derived stressors. As an example, prioritizing beach renourishment on an inhabited barrier island to support recovery of sea turtles will likely be more successful if the surrounding area enforces a lighting ordinance, which reduces disorienting light pollution that negatively impacts hatchling success (Witherington and Martin 2000).

7. Invest in adaptive management and related integration and delivery of ecosystem science, monitoring data and other information. Synthesis of information regarding project outcomes and change over time is critical to understand the role climate change and sea level rise are playing in project sustainment over time. Learning from projects can reduce uncertainty and increase the likelihood of success for future projects; however, this learning can only take place if information is collected consistently and is readily accessible to scientists and restoration managers.

8. Set realistic expectations regarding what restoration can reasonably accomplish. Restoration projects that are located in areas that are expected to become inundated by 2060 may still be viable projects if their restoration creates or conserves habitat for endangered species or provides storm surge protection for vulnerable communities, providing time for additional management or adaptation activities to occur. However, these projects should be undertaken with the full acknowledgement that their benefits are likely temporary and that additional investments will likely be required.

9. Apply a translational ecology approach to restoration project selection. Development and selection of projects by collaborative teams of ecologists, social scientists and decision makers who jointly take into account ecological, economic, political and social considerations in selecting projects can result in improved decision-making and projects that achieve multiple benefits while potentially spurring innovative approaches to project design and implementation (Enquist et al. 2017).

10. Set aside a percentage of DWH funds for projects that directly address climate risks. As climate change continues to alter ecosystems and increase risk to humans and built infrastructure, costs to adapt and mitigate undesirable impacts will continue to rise. Focusing $10 \%$, or $\$ 2$ Billion of DWH funds on projects that could reasonably be expected to withstand and/or mitigate the projected impacts of SLR could provide short-term benefits while serving as a down payment for future restoration and mitigation efforts.

\section{Conclusion}

The framework described above can be incorporated into DWH project selection discussions without disrupting existing processes or creating extensive data or analysis needs. However, these principles can also be expanded upon to develop a quantitative matrix for considering whether a proposed project's outcomes are sustainable over a period of decades given potential impacts of climate change. Ultimately, it is up to DWH funders to decide whether they want ecosystem investments made today to still be paying dividends 20 to 30 years from now.

Open Access This article is distributed under the terms of the Creative Commons Attribution 4.0 International License (http:// creativecommons.org/licenses/by/4.0/), which permits unrestricted use, distribution, and reproduction in any medium, provided you give appropriate credit to the original author(s) and the source, provide a link to the Creative Commons license, and indicate if changes were made.

\section{References}

Anderson JB, Wallace DJ, Simms AR, Rodriguez AB, Milliken KT (2014) Variable response of coastal environments of the northwestern Gulf of Mexico to sea-level rise and climate change: implications for future change. Marine Geology 352:348-366. https://doi. org/10.1016/j.margeo.2013.12.008

Baldera A, Hansen D, Kraft B (2018) Selecting indicators to monitor outcomes across projects and multiple restoration programs in the Gulf of Mexico. Ecological Indicators 89:559-571. https://doi.org/ 10.1016/j.ecolind.2018.01.025

Bregy JC, Wallace DJ, Minzoni RT, Cruz VJ (2018) 2500-year Paleotempestological record of intense storms for the northern Gulf of Mexico, United States. Marine Geology 396:26-42. https://doi.org/10.1016/j.margeo.2017.09.009

Bureau of Economic Analysis (2017) Gross domestic product by state, $4^{\text {th }}$ quarter and annual 2016. https://apps.bea.gov/regional/histdata/ releases $/ 0517 \mathrm{gdpstate} / \mathrm{index.cfm}$

Choi YD, Temperton VM, Allen EB, Grootjans AP, Halassy M, Hobbs RJ, Naeth MA, Torok K (2008) Ecological restoration for future sustainability in a changing environment. Ecoscience 15(1):53-64. https://doi.org/10.2980/1195-6860(2008)15[53:ERFFSI]2.0.CO;2

Coastal Protection and Restoration Authority (CPRA) (2017) Louisiana's comprehensive master plan for a sustainable coast. Coastal Protection and Restoration Authority of Louisiana. Baton Rouge, LA. 186 pp. http://coastal.la.gov/wp-content/uploads/2017/04/ 2017-Coastal-Master-Plan

Crowe KA, Parker WH (2008) Using portfolio theory to guide reforestation and restoration under climate change scenarios. Climatic Change 89:355-370. https://doi.org/10.1007/s10584-007-9373-x

Dalyander PS, Meyers M, Mattsson B, Steyer G, Godsey E, McDonald J, Byrnes M, Ford M (2016) Use of structured decision-making to explicitly incorporate environmental process understanding in management of coastal restoration projects: case study on barrier islands of the northern Gulf of Mexico. Journal of Environmental Management 183:497-509. https://doi.org/10.1016/j.jenvman. 2016.08.078 
Davis MS, Boyer ND (2017) Financing options for coastal protection and restoration in Louisiana. Tulane Institute on Water Resources Law \& Policy

Deepwater Horizon Oil Spill Trustees (2016) Final programmatic damage assessment and restoration plan (PDARP) and final programmatic environmental impact statement (PEIS). http://www. gulfspillrestoration.noaa.gov/restoration-planning/gulf-plan

Department of Justice (2016) Fact Sheet: proposed consent decree with BP for the deepwater horizon/macondo well oil Spill. 3 pp. https:// www.justice.gov/enrd/file/780311/download

Enquist CAF, Jackson ST, Garfin GM, Davis FW, Gerber LR, Littell JA, Shaw MR (2017) Foundations of translational ecology. Frontiers in Ecology and the Environment 15(10):541-550. https://doi.org/10. 1002/fee. 173

Environmental Law Institute (ELI) (2014) Building bridges: connecting the overlapping goals, resources, and institutions of Gulf of Mexico restoration and conservation. $81 \mathrm{pp}$. http://eli-ocean.org/wp-content/ blogs.dir/2/files/Full-Report-Final.pdf

Enwright NM, Griffith KT, Osland MJ (2016) Barriers to and opportunities for landward migration of coastal wetland with sea-level rise. Frontiers in Ecology and the Environment 14:307-316. https://doi. org/10.1002/fee. 1282

Estenoz S, Bush E (2015) Everglades restoration science and decisionmaking in the face of climate change: a management perspective. Environmental Management 55(4):876-883. https://doi.org/10. 1007/s00267-015-0452-x

Gulf Coast Ecosystem Restoration Council (2013) Restoring the Gulf Coast's Ecosytem and economy. Secretary Pritzker, Department of Commerce, Chair. 32 pp. https://www.restorethegulf.gov/sites/ default/files/Initial\%20Comprehensive\%20Plan\%20Aug\%202013. pdf

Gulf Coast Ecosystem Restoration Council (2016) Comprehensive Plan Update 2016, Restoring the Gulf Coast's Ecosystem and Economy. Secretary Vilsack, Department of Agriculture, Chair. 32 pp. https:// www.restorethegulf.gov/sites/default/files/CO-PL_20161208_ CompPlanUpdate_English.pdf

Gulf Coast Ecosystem Restoration Task Force (2011) Gulf of Mexico regional ecosystem restoration strategy. Final Report. 132 pp. http://www.epa.gov/gulfcoasttaskforce/pdfs/GulfCoastReport Full_12-04_508-1.pdf

Harris JA, Hobbs RJ, Higgs E, Aronson J (2006) Ecological restoration and global climate change. Restoration Ecology 14(2):170-176. https://doi.org/10.1111/j.1526-100X.2006.00136.x

Kim EJ (2015) The role of five gulf coast states under cooperative federalism: allocation of the Gulf coast restoration trust fund under the RESTORE act and state initiatives for large-scale ecosystem restoration. Southern University Law Review 43:119-148

Mahmoud M, Liu Y, Hartmann H, Stewart S, Wagnerer T, Semmens D, Stewart R, Gupta H, Dominguez D, Dominguez F, Hulse D, Letchr R, Rashleigh B, Smith C, Street R, Ticehurst J, Twery M, van Delden H, Waldick R, White D, Winter L (2009) A formal framework for scenario development in support of environmental decision-making. Environmental Modeling \& Software 24(7):798-808. https://doi.org/10.1016/j.envsoft.2008.11.010

Morris R, Konlechner TM, Ghisalberti M, Swearer SE (2018) From grey to green: efficacy of eco-engineering solutions for nature-based coastal defence. Global Change Biology 24(5):1827-1842. https:// doi.org/10.1111/gcb.14063

National Ocean Service, NOAA (2011) The Gulf of Mexico at a glance: a second glance. U.S. Department of Commerce, Washington, D.C. https://sero.nmfs.noaa.gov/outreach_education/gulf_b_wet/ applying_for_a_gulf_b_wet_grant/documents/pdfs/noaas_gulf_of mexico_at_a_glance_report.pdf

Passeri DV, Hagen SC, Medeiros C, Bilskie MV, Alizad K, Wang D (2015) The dynamics of sea level rise on low-gradient coastal landscapes: a review. Earth's Future 3(6):159-181. https://doi.org/10. 1002/2015EF000298

Pendleton EA, Barras JA, Williams SJ, Twichell DC (2010) Coastal vulnerability of the northern Gulf of Mexico to sea-level rise and coastal change. US Geological Survey Open-File Report 2010-1146. United States Geological Survey, Department of the Interior, Washington D.C. https:/pubs.usgs.gov/of/2010/1146/pdf/ofr20101146.pdf

Peterson MS, Waggy GL, Woodrey MS (eds) (2007) Grand Bay National Estuarine Research Reserve: an ecological characterization. Grand Bay National Estuarine Research Reserve, Moss Point, Mississippi. 1-268 pp. http://grandbaynerr.org/wp-content/uploads/2010/12/ Grand-Bay-National-Estuarine-Research-Reserve-Site-ProfileFinal-Draft-01Oct2007.pdf

Polasky S, Carpenter SR, Folke C, Keeler B (2011) Decision-making under great uncertainty: environmental management in an era of global change. Trends in Ecology and Evolution 26(8):398-404. https://doi.org/10.1016/j.tree.2011.04.007

Powell EJ, Tyrrell MC, Milliken A, Tirpak JM, Staudinger MD (2017) A synthesis of thresholds for focal species along the U.S. Atlantic and gulf coasts: a review of research and applications. Ocean \& Coastal Management 148:75-88. https://doi.org/10.1016/j.ocecoaman. 2017.07.012

Ramseur J, Hagerty CL (2014) Deepwater horizon oil spill: recent activities and ongoing developments. Washington D.C. digital.library. unt.edu/ark:/67531/metadc306481/

Reguero BG, Beck MW, Bresch DN, Calil J, Meliane I (2018) Comparing the cost effectiveness of nature-based and coastal adaptation: a case study from the Gulf coast of the United States. PLoS One 13(4):e0192132. https://doi.org/10.1371/journal.pone.0192132

Stoutenborough JW, Vedlitz A (2015) Knowledge, information, and view of climate change: an examination of coastal stakeholders along the Gulf of Mexico. Climate 3:983-998. https://doi.org/10.3390/ cli3040983

Strauss B, Tebaldi C, Kulp S, Cutter S, Emrich C, Rizza D, Yawitz (2015) Alabama and the surging sea: a vulnerability assessment with projections for sea level rise and coastal flood risk. Climate Central Research Report. 30 pp. http://sealevel.climatecentral.org/uploads/ ssrf/AL-Report.pdf

Theuerkauf EJ, Rodriguez AB, Fegley SR, Luettich RA (2014) Sea level anomalies exacerbate beach erosion. Geophysical Research Letters 41(14):5139-5147. https://doi.org/10.1002/2014GL060544

Watson A, Reece J, Tirpack BE, Edwards CK, Geselbracht L, Woodrey M, LaPeyre, M, Dalyander PS (2015) The Gulf coast vulnerability assessment: mangrove, tidal emergent marsh, barrier islands, and oyster reef. http://gulfcoastprairielcc.org/science/science-projects/ gulf-coast-vulnerability-assessment/

Witherington BE and Martin RE (2000) Understanding, assessing and resolving light pollution problems on sea turtle nesting beaches. Florida Fish and Wildlife Conservation Commission, Florida Marine Research Institute Technical Reports TR-2. St. Petersburg, FL. $84 \mathrm{pp}$

Publisher's Note Springer Nature remains neutral with regard to jurisdictional claims in published maps and institutional affiliations. 